\title{
INFLUENCE OF PRE-HARVEST POTASSIUM AND SILICON FOLIAR APPLICATION ON QUALITY AND STORABILITY OF SWEET PEPPER
}

\author{
ATRESS, AMAL, S. H. ${ }^{1}$ and I. A. S. RASHID ${ }^{2}$ \\ 1. Department of Vegetable Handling, Horticulture Research Institute, ARC, Giza, \\ Egypt. \\ 2. Department of Postharvest Diseases, Plant Pathology Research Institute, ARC, \\ Giza, Egypt. \\ (Manuscript received 27 July 2016)
}

\begin{abstract}
$\mathrm{T}$ his experiment was carried out in the two successive seasons 2013/ 2014 and 2014/2015 to study the effect of the pre-harvest foliar applications of potassium silicate at concentration of 4 and $8 \mathrm{ml} / \mathrm{l}$, potassium thiosulfate at concentration of 1.5 and $3 \mathrm{ml} / \mathrm{l}$, and Harvars at concentration of 2.5 and $5 \mathrm{ml} / \mathrm{l}$ on the quality and storability of sweet pepper fruits (Capsicum annuum L.) Cv. Sonar. The obtained results showed that spraying sweet pepper plants with potassium silicate or potassium thiosulphate significantly improved fruit quality parameters at harvest time i.e., fruit weight, lightness and hue angle. Concerning storage experiment, the obtained results indicated that sweet pepper fruits received pre-harvest potassium silicate at a concentration of $4 \mathrm{ml} / \mathrm{l}$ effectively displayed sweet pepper fruits with glossy and vivid green appearance, maintained TSS\%, and reduced the degradation of ascorbic acid content of sweet pepper fruits during storage at $8^{\circ} \mathrm{C}$ and $95 \%$ RH for 21 days.
\end{abstract}

Key words: Sweet pepper, potassium foliar applications, storage.

\section{INTRODUCTION}

Sweet pepper (Capsicum annuum L.) is one of the most important commercial vegetables. However, it is a highly perishable crop with short shelf life. Pepper fruits are rich in vitamins, such as A and C, and are low in calories (Howard et al., 1994). The quality attributes during storage of fresh pepper fruits are affected by water loss, chilling injury, and pathological disorders, which reduce quality and acceptability of fruits. So, it is recommended to store pepper fruits between $7-10{ }^{\circ} \mathrm{C}$ and $95 \% \mathrm{RH}$ to stay in good quality for 2-3 weeks without chilling injury (Sethu et al., 1996, Kader, 2002, and Maalekuu et al., 2002, and smith et al., 2006). Pre-harvest plant nutrition is a major factor effect on fruit and vegetable quality (Sams, 1999). Potassium (K) has been recognized as an important nutrient for crop quality, because it is involved in plants in several metabolic processes such as enzyme activation, osmotic control, and carbohydrate production (Krauss, 2000, and Cong and Hardter, 2001). Silicon (Si) also, plays different roles in plant growth and development; improve soil fertility, 
enhance plant resistant to diseases and pests, increase photosynthesis, regulate respiration and increase the tolerance of plant to elements toxicity (Hou et al., 2006). Pre-harvest applications of $\mathrm{K}$ and $\mathrm{Si}$ during plant growth and fruit development increased fruit weight and chlorophyll content of leaves in strawberry Afifi, (2016). Improved postharvest fruit quality, and increased TSS and ascorbic acid in horticulture crops (Hou et al., 2006), in melons (Jifon et al., 2009), in Sweet pepper (El-Bassiony et al., 2010), in tomato (Lyyakkannu et al., 2011), in Muskmelon (Jifon and Lester 2012), in strawberry Afifi, (2016).

The aim of this work was to investigate the impact of pre-harvest foliar applications of potassium silicate as a source of silicon, and potassium thiosulfate and Harvars as sources of potassium on quality and storability of sweet pepper fruits.

\section{MATERIALS AND METHODS}

\section{The field experiment}

This experiment was carried out in the two successive seasons 2013/ 2014 and 2014/2015. Sweet pepper seeds (Capsicum annuum L.) CV. Sonar from Slwis \& Gloot Company, Holland, were sowed on $1^{\text {st }}$ day of July in both seasons in a plastic house using seedling trays of 84 cells. The trays were filled with a commercial plastic house transplanting mixture [1 peat moss: 1 vermiculite $(\mathrm{v} / \mathrm{v})]$ amended with macroand micro-nutrients. Sowing was carried out and each cell of the tray had one seed covered with $0.5 \mathrm{~cm}$ of the sowing mixture. After 30 days, seedlings were transplanted to a plastic house of an area $540 \mathrm{~m}^{2}(60 \mathrm{~m}$ long $\times 9 \mathrm{~m}$ width $\times 3 \mathrm{~m}$ height). The area of each experimental plot was $10 \mathrm{~m}^{2}$ consisted of one row (10 m length with $1 \mathrm{~m}$ width). Seedlings were planted on the two sides of each ridge (zigzag pattern) at $50 \mathrm{~cm}$ apart. The experiment was laid out in a randomized complete block design with three replicates. The soil texture of the experiment was clay loamy as represented in Table 1.

Agricultural practices as harrowing and pests and diseases control were carried out according to the recommendations of ministry of agriculture for sweet pepper planting. 
Table1. The physiochemical properties of the plastic house soil used for sweet pepper planting (average two seasons).

\begin{tabular}{|c|c|c|c|c|c|c|}
\hline $\begin{array}{c}\text { Soil } \\
\text { texture }\end{array}$ & $\begin{array}{c}\text { Organic } \\
\text { matter } \\
(\%)\end{array}$ & $\mathrm{pH}$ & $\begin{array}{c}\text { E.C. } \\
\left.(\mathrm{dS} \mathrm{m})^{-1}\right)\end{array}$ & $\begin{array}{c}\text { Available N } \\
(\mathrm{ppm})\end{array}$ & $\begin{array}{c}\text { Available P } \\
(\mathrm{ppm})\end{array}$ & $\begin{array}{c}\text { Available K } \\
(\mathrm{ppm})\end{array}$ \\
\hline $\begin{array}{c}\text { Clay } \\
\text { loamy }\end{array}$ & 1.2 & 8.22 & 0.446 & 42.5 & 7.65 & 337 \\
\hline
\end{tabular}

Soil sample was taken from $25 \mathrm{~cm}$ soil surface

Soil samples were analyzed by Soil, Water and Environment Res. Inst. Agric. Res.

Center. The chemical properties of the soil were determined using the methods described in Association of Official Agriculture Chemists AOAC (1990).

\section{Potassium foliar applications were applied as follow:}

1. Potassium silicate $\mathrm{K}_{2} \mathrm{SiO}_{3} 4 \mathrm{ml} / \mathrm{l}$.

2. Potassium silicate $\mathrm{K}_{2} \mathrm{SiO}_{3} 8 \mathrm{ml} / \mathrm{l}$.

3. Potassium thiosulfate $\mathrm{K}_{2} \mathrm{~S}_{2} \mathrm{O}_{3}$ (KTS) $1.5 \mathrm{ml} / \mathrm{l}$.

4. Potassium thiosulfate $\mathrm{K}_{2} \mathrm{~S}_{2} \mathrm{O}_{3}$ (KTS) $3 \mathrm{ml} / \mathrm{l}$.

5. Harvars $\left(60 \% \mathrm{~K}_{2} \mathrm{O}\right) 2.5 \mathrm{ml} / \mathrm{l}$.

6. Harvars $\left(60 \% \mathrm{~K}_{2} \mathrm{O}\right) 5 \mathrm{ml} / \mathrm{l}$.

7. Controll (sprayed with tap water).

Potassium silicate $\left(10 \% \mathrm{~K}_{2} \mathrm{O}+25 \% \mathrm{SiO}_{2}\right)$ and $\mathrm{KTS}\left(36 \% \mathrm{~K}_{2} \mathrm{O}+25 \% \mathrm{SiO}_{2}\right)$ were purchased from El-Gomhoria Co. Egypt. Meanwhile, Harvars (N-P-K, 7: 7: 60), was purchased from Haval Company for Industrial Investments and Chemical Materials, Egypt. Plants were sprayed 4 times during the growing period 15, 30, 45-and 60 days from transplanting.

The obtained data in this experiment were recorded as follows:

\section{Fruit quality parameters}

A random sample of 10 fruits from each replicate was taken at harvest to evaluate fruit quality parameters: average fruit weight (g), Skin color measurement was measured using a Minolta Chroma Meter, model CR-200. Calibration was done by a white plate before use. Color changes were quantified by calculating lightness ( $L$ ) and hue angle in tested samples during storage. hue angle is defined as a color wheel, with pure redness at an angle of $0^{\circ}$, yellow at $90^{\circ}$, pure greenness at $180^{\circ}$, and blue at $270^{\circ}$ Xing et al.,(2011). Total soluble solids (TSS) \% was determined by using a hand Refractometer according to the methods mentioned in A.O.A.C. (2000). Titratable acidity percentage in pepper was measured by titration with $0.1 \mathrm{NaOH}$ and 
calculated as citric acid according to AOAC (2000). Ascorbic acid content (as indicator for vitamin C.) was determined (as fresh samples of fruits) by titration method using 2, 6 dicloro phenol indophenol as dicribed in AOAC (2000).

\section{The storage experiment}

Sweet pepper fruits were harvested after 70 days from transplanting at a commercial maturity (green stage) and transferred to the laboratory of the Vegetable Handling Department, Horticulture Research Center, within two hours of harvest and kept overnight at $8^{\circ} \mathrm{C}$ and $90-95 \%$ relative humidity ( $\mathrm{RH}$ ). The following morning, the uniform fruits in size, without physical defects or fungal infection from each treatment were selected and placed in carton boxes at the diminutions of $30 \times 35 \times 10 \mathrm{~cm}$. Each box contained $2 \mathrm{~kg}$ from pepper fruits as one replicate. Nine replicates from each treatment were stored at $8^{\circ} \mathrm{C}$ and $95 \% \mathrm{RH}$ for 21 days. The sample for each treatment was taken at random in three replicates and arranged in a complete randomized design. Samples were evaluated for the changes in the quality parameters at 0 and 7, 14 and 21 days during storage as follows:

1. Weight loss percentage (estimated according to the following equation: Initial plant weight - plant weight at sampling date

Weight loss $\%=$ $\mathrm{X} 100$

Initial plant weight

2. Skin color (lightness and hue angle), Total soluble solids (TSS \%), Titrable acidity (TA \%), and ascorbic acid content (vitamin C) were measured as described previous in the field experiment.

3. Visual quality of pepper fruits were determined according to the following score system: $9=$ excellent, $7=$ good, $5=$ fair, $3=$ poor, and $1=$ unusable. Where an average of 5 is fruit in the limit of shelf life. This scale depend on morphological defects such as shriveling (wilting), color change of fruit surface and the pathological disorders.

\section{Statistical analysis}

Data of the field experiment and cold storage experiment were statistically analyzed by using MSTAT statistical software and the treatments means were compared by using LSD at 0.05 level of probability according to Snedecor and Cochran (1980).

\section{RESULTS AND DISCUSSION}

\section{Fruit quality parameters}

Data presented in Table 2 reveal that all tested treatments produced sweet pepper fruit with higher average fruit weight without significant differences among them as compared with fruit sprayed with harvars at concentration of $2.5 \mathrm{ml} / \mathrm{l}$ or 
control, where control plants recorded the lowest average of fruit weight. Such results were in line with the work of Afifi, (2016), for potassium silicate on strawberry, and in a contradiction with the finding of Jifon et al. (2009) for potassium thiosulphate on melons. As regard to lightness it is clear from the data that our tested treatments significantly increased the lightness of sweet pepper fruit as compared with control. These results were true in the second season. Meanwhile, no significant differences were observed between control plants and plants treated with Harvars at the concentration of 2.5 or $5 \mathrm{ml} / \mathrm{l}$ in the first season. Our results were supported by Jayawardana et al., (2014) who found that foliar application of soluble silicon increase cuticle thickness of capsicum fruit. This in turn gives sweet pepper fruits the shiny appearance. With respect to hue angle, the same Table shows that our tested treatments were succeeded in producing sweet pepper fruit with clear green color without significant effect among them as compared to control. Our obtained results were in agreement with Silva et al., (2013) who investigated that spraying strawberry plants with $\mathrm{Si}$ increased the values of chlorophyll reading compared with control, and El-Bassiony et al., (2010) who found an increasing in the content of sweet pepper fruit from chlorophyll as the potassium rate increased. Concerning TSS\%, data listed in Table 2 displays that our studied treatments effectively increased TSS\% of sweet pepper fruits compared with control in both seasons. These results were in accordance with Afifi, (2016) for potassium silicate on strawberry and Jifon and Laster (2012) for potassium thiosulfate on muskmelon. Moreover, Sweet pepper fruits received potassium silicate at concentration of $4 \mathrm{ml} / \mathrm{l}$ recorded the highest TSS\% as compared with the other treatments. Meanwhile, control fruits recorded the lowest TSS\% in both seasons. Regarding acidity $\%$ and ascorbic acid content, the obtained data reveal that our treatments hadn't any effect in either acidity \% or ascorbic acid content. Such results were in agreement with the finding of Afifi, (2016) regarding the effect of potassium silicate on the acidity of strawberry and disagree with El-Bassiony et al., (2010) regarding the effect of potassium on ascorbic acid content of sweet pepper. 
Table 2. Effect of pre- harvest foliar application of potassium and silicon on the quality parameters of sweet pepper fruits during 2013/2014 and 2014/2015 seasons.

\begin{tabular}{|c|c|c|c|c|c|c|}
\hline \multirow[b]{2}{*}{ Treatments } & \multicolumn{6}{|c|}{ Season $(2013 / 2014)$} \\
\hline & $\begin{array}{l}\text { Fruit } \\
\text { weight } \\
\text { (g) }\end{array}$ & Lightness & $\begin{array}{l}\text { hue } \\
\text { angle }\end{array}$ & TSS (\%) & $\begin{array}{c}\text { Acidity } \\
(\%)\end{array}$ & $\begin{array}{c}\text { Ascorbic } \\
\text { Acid } \\
\text { (mg/100g } \\
\text { f.w) }\end{array}$ \\
\hline Potassium silicate $4 \mathrm{ml} / \mathrm{l}$ & 162.09 & 33.10 & 123.04 & 5.00 & 0.17 & 112.44 \\
\hline Potassium silicate $8 \mathrm{ml} / \mathrm{l}$ & 162.23 & 33.28 & 122.39 & 4.66 & 0.17 & 112.55 \\
\hline Potassium thiosulfate $1.5 \mathrm{ml} / \mathrm{I}$ & 160.31 & 33.82 & 122.05 & 4.50 & 0.14 & 112.08 \\
\hline Potassium thiosulfate $3 \mathrm{ml} / \mathrm{l}$ & 157.57 & 32.86 & 122.61 & 4.33 & 0.15 & 112.10 \\
\hline Harvars $2.5 \mathrm{ml} / \mathrm{l}$ & 143.86 & 31.87 & 121.89 & 4.33 & 0.15 & 112.13 \\
\hline Harvars $5 \mathrm{ml} / \mathrm{l}$ & 151.27 & 31.92 & 122.51 & 4.50 & 0.16 & 112.43 \\
\hline Control & 120.88 & 31.43 & 121.95 & 4.00 & 0.13 & 112.25 \\
\hline LSD at $5 \%$ Level & 12.77 & 0.82 & 0.74 & 0.33 & N.S. & N.S. \\
\hline & \multicolumn{6}{|c|}{ Season $(2014 / 2015)$} \\
\hline Treatments & $\begin{array}{l}\text { Fruit } \\
\text { weight } \\
\text { (g) }\end{array}$ & Lightness & $\begin{array}{l}\text { hue } \\
\text { angle }\end{array}$ & TSS (\%) & $\begin{array}{c}\text { Acidity } \\
(\%)\end{array}$ & $\begin{array}{l}\text { Ascorbic } \\
\text { Acid } \\
\text { (mg/100g } \\
\text { f.w) }\end{array}$ \\
\hline Potassium silicate $4 \mathrm{ml} / \mathrm{l}$ & 166.38 & 32.19 & 123.11 & 4.83 & 0.15 & 113.55 \\
\hline Potassium silicate $8 \mathrm{ml} / \mathrm{l}$ & 162.09 & 32.69 & 122.34 & 4.66 & 0.15 & 113.80 \\
\hline Potassium thiosulfate $1.5 \mathrm{ml} / \mathrm{l}$ & 161.32 & 33.40 & 122.23 & 4.66 & 0.15 & 113.01 \\
\hline Potassium thiosulfate $3 \mathrm{ml} / \mathrm{l}$ & 158.88 & 32.86 & 122.43 & 4.33 & 0.14 & 113.58 \\
\hline Harvars $2.5 \mathrm{ml} / \mathrm{l}$ & 148.24 & 32.05 & 122.32 & 4.50 & 0.15 & 113.80 \\
\hline Harvars $5 \mathrm{ml} / \mathrm{l}$ & 155.82 & 32.57 & 122.54 & 4.33 & 0.15 & 113.76 \\
\hline Control & 125.62 & 31.03 & 121.80 & 4.00 & 0.12 & 111.70 \\
\hline LSD at $5 \%$ Level & 13.03 & 0.91 & 1.22 & 0.32 & N.S. & N.S. \\
\hline
\end{tabular}

\section{Weight loss\%}

Water loss is one of the most important factors that negatively impact pepper fruit during shipment, storage and marketing (Maalekuu et al., 2002). As shown in Table 3, weight loss \% of pepper fruit increased linearly as the storage time increased. This increase may be due to fruit transpiration as reported by Roa et al. (2011). In respect to treatments, all pre-harvest treatments significantly reduced weight loss percentage as compared with the control. In addition, sweet pepper fruits received pre-harvest potassium silicate as drenches of 4 and $8 \mathrm{ml} / \mathrm{l}$ and potassium thiosulfate as drenches of 1.5 and $3 \mathrm{ml} / \mathrm{l}$ effectively, controlled weight loss percentage without significant impact between them as compared with the other treatments.

These results were true in both seasons. Such results are in accordance with those reported by Tesfay et al. (2011), who pointed out to the role of silicon in maintaining the moisture of avocado fruit and delaying weight loss, and, in agreement with Afifi, (2016), for potassium silicate on strawberry. Also, Tarabih et al. (2014) found that silicon might reduce respiration rate of apple fruit and inhibited the physiological processes, which in turn reduces weight loss. In general, the interaction between treatments and storage period was significant and showed that pre-harvest treatment of sweet pepper fruits with potassium silicate displayed the lowest weight loss $\%$ during all storage periods at $8^{\circ} \mathrm{C}$ and $95 \% \mathrm{RH}$. 
Table 3. Effect of pre-harvest potassium and silicon treatments on weight loss $\%$ and lightness of sweet pepper fruits during storage.

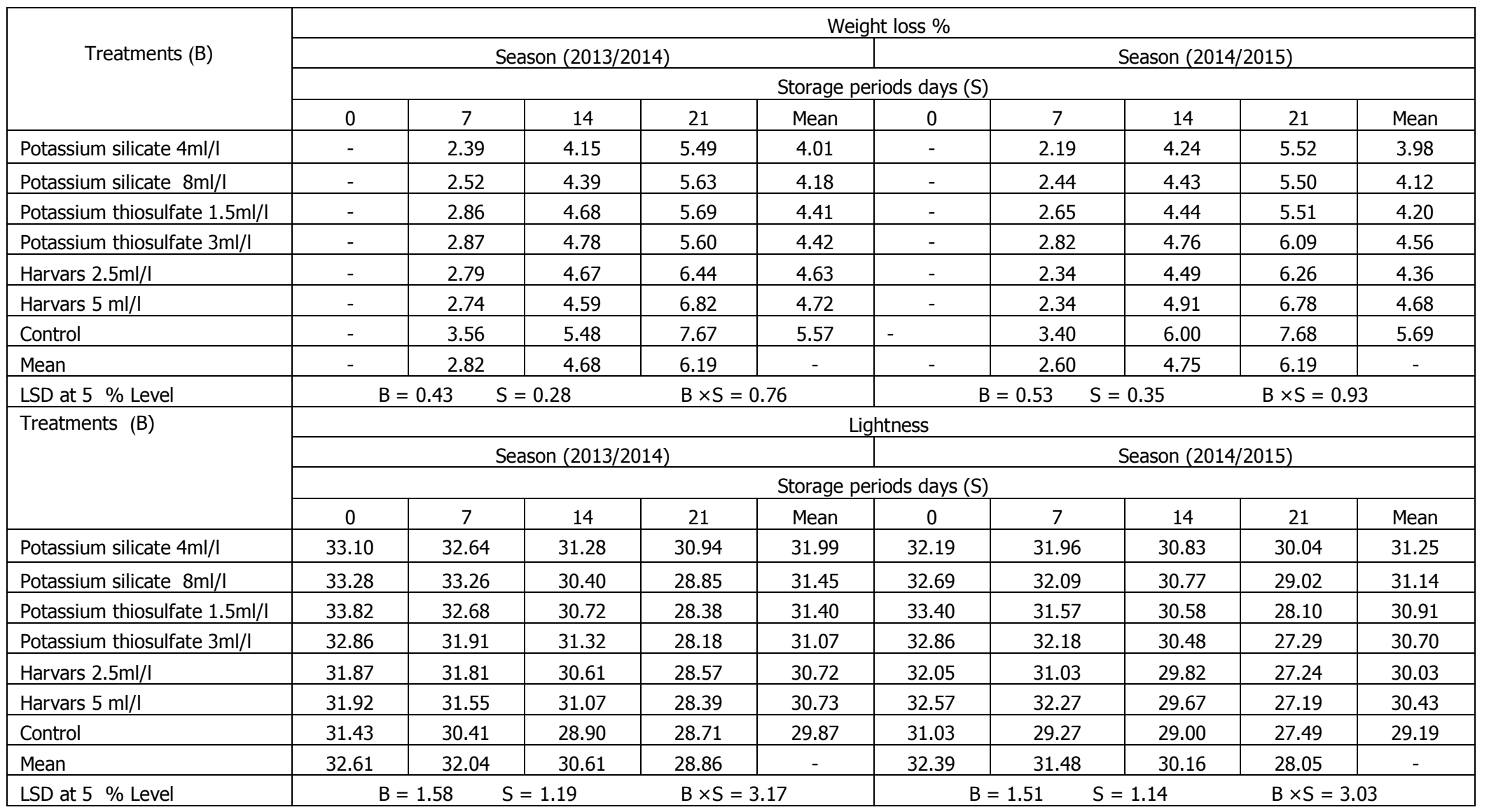




\section{Skin color}

Data presented in Tables 3 and 4 reflected that a slight decrease in sweet pepper fruits lightness and hue angle was occurred coincided with the storage time prolongation. The decreasing in the lightness may be correlated with water loss which negatively affected on the luminosity of pepper fruits. Meanwhile, the decreasing in hue angle may be attributed to chlorophyll degradation which associated to fruit senescence. Also, the same Table shows that our tested treatments displayed sweet pepper fruits with shinny and vivid green color as compared with the control which exhibited less lightness and less green color. In addition, spraying samples with potassium silicate at concentration of 4 and $8 \mathrm{ml} / /$ displayed much better lightness and greenness as compared with other treatments and the control. These results might be attributed to the role of potassium silicate in delaying fruit senescence which in turn displayed the external and the internal color of fruits lighter than control (Afifi, 2016). These results were true in the first season. On the other hand, all studied treatments were more effective in keeping pepper fruits with glossy and vivid green appearance without considerable effects between them in the second season. The interaction between treatments and storage period was significant and indicated that potassium silicate treatment at the two concentrations 4 and $8 \mathrm{ml} / \mathrm{l}$ effectively maintained higher lightness and hue angle values of sweet pepper fruits for 21 days storage at $8{ }^{\circ} \mathrm{C}$ and $95 \% \mathrm{RH}$.

\section{Visual quality}

To provide high quality produce, it is required to start from high quality material, i.e., fertilization, production technology system and nutrient, where the best quality of any commodity exists at moment of harvest. From this point, quality cannot be improved, only maintained (Cheisa et al., 2003). The visual quality scale depends on morphological defects such as shriveling (wilting), color changes of fruit surface and the pathological disorders. Wills et al. (1998) reported that a bell pepper quality declined after $5 \%$ weight loss. Results in Table 4 revealed that visual quality score declined significantly with the prolongation of the storage period without chilling injury or pathological symptoms. This decline may due to water loss which cause shriveling and reduce glossiness and acceptability of pepper fruits (Maalekuu et al., 2002 and Smith et al., 2006). 
Table 4. Effect of pre-harvest potassium and silicon treatments on hue angle and visual quality of sweet pepper fruits during storage.

\begin{tabular}{|c|c|c|c|c|c|c|c|c|c|c|}
\hline \multirow{4}{*}{ Treatments (B) } & \multicolumn{10}{|c|}{ hue angle } \\
\hline & \multicolumn{5}{|c|}{ Season $(2013 / 2014)$} & \multicolumn{5}{|c|}{ Season $(2014 / 2015)$} \\
\hline & \multicolumn{10}{|c|}{ Storage periods days (S) } \\
\hline & 0 & 7 & 14 & 21 & Mean & 0 & 7 & 14 & 21 & Mean \\
\hline Potassium silicate $4 \mathrm{ml} / \mathrm{l}$ & 123.04 & 122.25 & 122.03 & 121.23 & 122.14 & 123.11 & 122.16 & 121.66 & 121.32 & 122.06 \\
\hline Potassium silicate $8 \mathrm{ml} / \mathrm{l}$ & 122.39 & 121.91 & 121.76 & 121.43 & 121.87 & 122.34 & 122.25 & 121.86 & 121.53 & 122.00 \\
\hline Potassium thiosulfate $1.5 \mathrm{ml} / \mathrm{l}$ & 122.05 & 121.03 & 121.74 & 121.61 & 121.60 & 122.23 & 122.00 & 121.90 & 121.62 & 121.94 \\
\hline Potassium thiosulfate $3 \mathrm{ml} / \mathrm{l}$ & 122.61 & 122.37 & 121.69 & 120.82 & 121.87 & 122.43 & 122.38 & 121.88 & 120.72 & 121.85 \\
\hline Harvars $2.5 \mathrm{ml} / \mathrm{l}$ & 121.89 & 121.69 & 121.43 & 120.46 & 121.36 & 122.32 & 121.68 & 121.51 & 121.28 & 121.69 \\
\hline Harvars $5 \mathrm{ml} / \mathrm{l}$ & 122.51 & 121.50 & 121.33 & 120.58 & 121.48 & 122.54 & 121.73 & 121.63 & 120.72 & 121.65 \\
\hline Control & 121.95 & 121.75 & 120.97 & 120.63 & 121.23 & 121.80 & 121.09 & 120.38 & 119.58 & 120.71 \\
\hline Mean & 122.34 & 121.79 & 121.56 & 120.96 & - & 122.40 & 121.89 & 121.54 & 120.96 & - \\
\hline LSD at $5 \%$ Level & & 0.78 & & $\mathrm{~B} \times \mathrm{S}=1$. & & & 0.62 & .47 & $\mathrm{~B} \times \mathrm{S}=$ & \\
\hline \multirow{4}{*}{ Treatments (B) } & \multicolumn{10}{|c|}{ Visual quality } \\
\hline & \multicolumn{5}{|c|}{ Season $(2013 / 2014)$} & \multicolumn{5}{|c|}{ Season $(2014 / 2015)$} \\
\hline & \multicolumn{10}{|c|}{ Storage periods days (S) } \\
\hline & 0 & 7 & 14 & 21 & Mean & 0 & 7 & 14 & 21 & Mean \\
\hline Potassium silicate $4 \mathrm{ml} / \mathrm{l}$ & 9.00 & 9.00 & 7.00 & 7.00 & 8.00 & 9.00 & 9.00 & 7.00 & 7.66 & 8.16 \\
\hline Potassium silicate $8 \mathrm{ml} / \mathrm{l}$ & 9.00 & 9.00 & 7.00 & 6.00 & 7.75 & 9.00 & 9.00 & 7.00 & 6.33 & 7.83 \\
\hline Potassium thiosulfate $1.5 \mathrm{ml} / \mathrm{l}$ & 9.00 & 9.00 & 7.00 & 5.33 & 7.58 & 9.00 & 9.00 & 7.00 & 6.33 & 7.83 \\
\hline Potassium thiosulfate $3 \mathrm{ml} / \mathrm{l}$ & 9.00 & 9.00 & 7.00 & 5.00 & 7.50 & 9.00 & 8.33 & 6.66 & 5.33 & 7.33 \\
\hline Harvars $2.5 \mathrm{ml} / \mathrm{l}$ & 9.00 & 8.00 & 6.33 & 5.33 & 7.16 & 9.00 & 8.00 & 7.00 & 5.66 & 7.41 \\
\hline Harvars $5 \mathrm{ml} / \mathrm{l}$ & 9.00 & 8.33 & 6.33 & 6.00 & 7.41 & 9.00 & 8.33 & 6.66 & 5.33 & 7.33 \\
\hline Control & 9.00 & 6.33 & 4.33 & 2.33 & 5.50 & 9.00 & 6.33 & 4.00 & 3.33 & 5.66 \\
\hline Mean & 9.00 & 8.38 & 6.42 & \multirow{2}{*}{\multicolumn{2}{|c|}{$\frac{5.28}{\mathrm{~B} \times \mathrm{S}=1.22}$}} & 9.00 & 8.28 & 6.47 & \multirow{2}{*}{\multicolumn{2}{|c|}{$\begin{array}{c}5.71 \\
B \times S=1.33 \\
\end{array}$}} \\
\hline LSD at $5 \%$ Level & \multicolumn{2}{|c|}{$B=0.61$} & & & & \multicolumn{2}{|c|}{$B=0.66$} & 0.50 & & \\
\hline
\end{tabular}


Concerning treatments, visual quality of sweet pepper was positively affected by potassium and silicon applications. All tested treatments showed higher visual quality score as compared to control. Moreover, sweet pepper fruits received prharvest potassium silicate at doses of $4,8 \mathrm{ml} / \mathrm{l}$ and potassium thiosulfate at dose of $1.5 \mathrm{ml} / \mathrm{l}$ displayed better acceptance without significant effect among them as compared with the others. These results are in agreement with Afifi, (2016) for potassium silicate on strawberry, who found that application of potassium silicate maintained the general appearance of fruit by reducing weight loss, decay and maintained the fruit quality. Moreover, Kaluwa et al. (2010) found that the main effect of $\mathrm{Si}$ application lies in suppression of respiration and ethylene production and enhance shelf life of avocado fruit. In addition, Tesafy et al. (2011) reported that treating avocado fruits with silicon lowered electrolyte leakage compared with control and improve quality parameters (mass loss and firmness), possibly due to $\mathrm{Si}$ deposition between cell wall and cell membrane, maintaining barrier against solute leakage, and also, Si may enhance activity of chitinases, peroxidase and polyphenol oxidase, and increase formation deposition of callose and hydrogen peroxidase (Shetty et al., 2012). Also, Si application improved strength and rididity of tissue (Liang et al., 2007).

The interaction between treatments and storage period was significant and indicted that pre-harvest foliar application of sweet pepper fruits with potassium silicate at a concentration of $4 \mathrm{ml} / \mathrm{l}$ exhibited pepper fruits with good appearance for 21days Meanwhile, fruits received potassium silicate at doses of $8 \mathrm{ml} / \mathrm{l}$ or potassium thiosulfate at dose of $1.5 \mathrm{ml} / /$ displayed good appearance for 14 days. On the other hand, control treatment reached its limited visual quality score after 7 days of storage at $8^{\circ} \mathrm{C}$ and $95 \% \mathrm{RH}$ in both seasons of study.

\section{Total soluble solids (TSS) \%}

As presented in Table 5, a significant increase was noted in our studied treatments regarding TSS\% as the prolongation of the storage period. The increment in TSS\% during storage may be attributed to the higher rate of dry matter loss and moisture loss through respiration and transpiration or the inversion of insoluble compounds to soluble substances. These results were observed in both seasons. Similar results were agreed with the findings of Xing et al., (2011) and Roa et al. (2011).

In respect to treatments, it is clear from the Table that pre-harvest spraying of sweet pepper with potassium silicate at the concentration of 4 or $8 \mathrm{ml} / \mathrm{l}$ efficiently maintained higher TSS \% as compared with others in the first season. Such results were in accordance with the finding of Stamatakis et al., (2003) on tomato and Tarabih et al., (2014) on apple who found that effect to reducing respiration rate, 
ethylene production and vital processes and Afifi, (2016) on strawberry. Meanwhile on the second season no significant difference was detected among our tested treatments and control. The interaction between treatments and storage period showed that the highest values of TSS\% were recorded in fruits treated with potassium silicate at the drenches of 4 and $8 \mathrm{ml} / \mathrm{l}$ in both seasons after 21 days of storage in $8^{\circ} \mathrm{C}$ and $95 \% \mathrm{RH}$.

\section{Titratable acidity (TA)}

As shown in Table 5, TA declined as the storage period extended. This result supported by Roa et al. (2011). This decline in TA may be due to the consumption of organic acids during respiration process. In respect to treatments, no statistical differences were detected among all tested treatments and the control treatment. The interaction between treatments and storage period was significant and showed that pre-harvest foliar application of potassium silicate at the two drenches kept higher TA\% for 14 days in both seasons.

\section{Ascorbic acid content}

It is obvious from Table 6 that a progressive decrease in ascorbic acid content was recorded as the storage extended. Such results are in conformity with Xing et al. (2011). The same Table indicated that all tested treatments efficiently maintained higher ascorbic acid content compared with the control treatment. This result was in a compliance with Jifon et al., (2009), on muskmelon, Jifon and Laster (2012) on melons and El-Bassiony et al., (2010) on sweet pepper. Moreover, pepper fruits received pr-harvest potassium silicate at a concentration of $4 \mathrm{ml} / \mathrm{l}$ maintained higher ascorbic acid content (102.33 and $100.95 \mathrm{mg} / 100 \mathrm{~g} \mathrm{f.w}$ ) in both seasons respectively, followed by fruit received potassium silicate at a concentration of $8 \mathrm{ml} / \mathrm{l}$ ( 96.78 and $96.2 \mathrm{mg} / 100 \mathrm{~g} \mathrm{f.w}$ ) in both season, respectively. Such results were obtained in both seasons and were in agreement with Afifi, (2016). The interaction between treatments and storage period indicated that sweet pepper fruit received potassium silicate at a concentration of $4 \mathrm{ml} / \mathrm{l}$ prevented the loss of ascorbic acid content during 21 days storage at $8^{\circ} \mathrm{C}$ and $95 \% \mathrm{RH}$.

\section{CONCLUSION}

It could be concluded that pre-harvest spraying of sweet pepper plants with potassium silicate or potassium thiosulphate significantly improved fruit quality parameters at harvest. Meanwhile, pre-harvest foliar application of potassium silicate at a concentration of $4 \mathrm{ml} / \mathrm{l}$ effectively maintained quality attributes of sweet pepper for 21 days storage at $8{ }^{\circ} \mathrm{C}$ and $95 \% \mathrm{RH}$. 
Table 5. Effect of pre-harvest potassium and silicon treatments on TSS \%and acidity of sweet pepper fruits during storage.

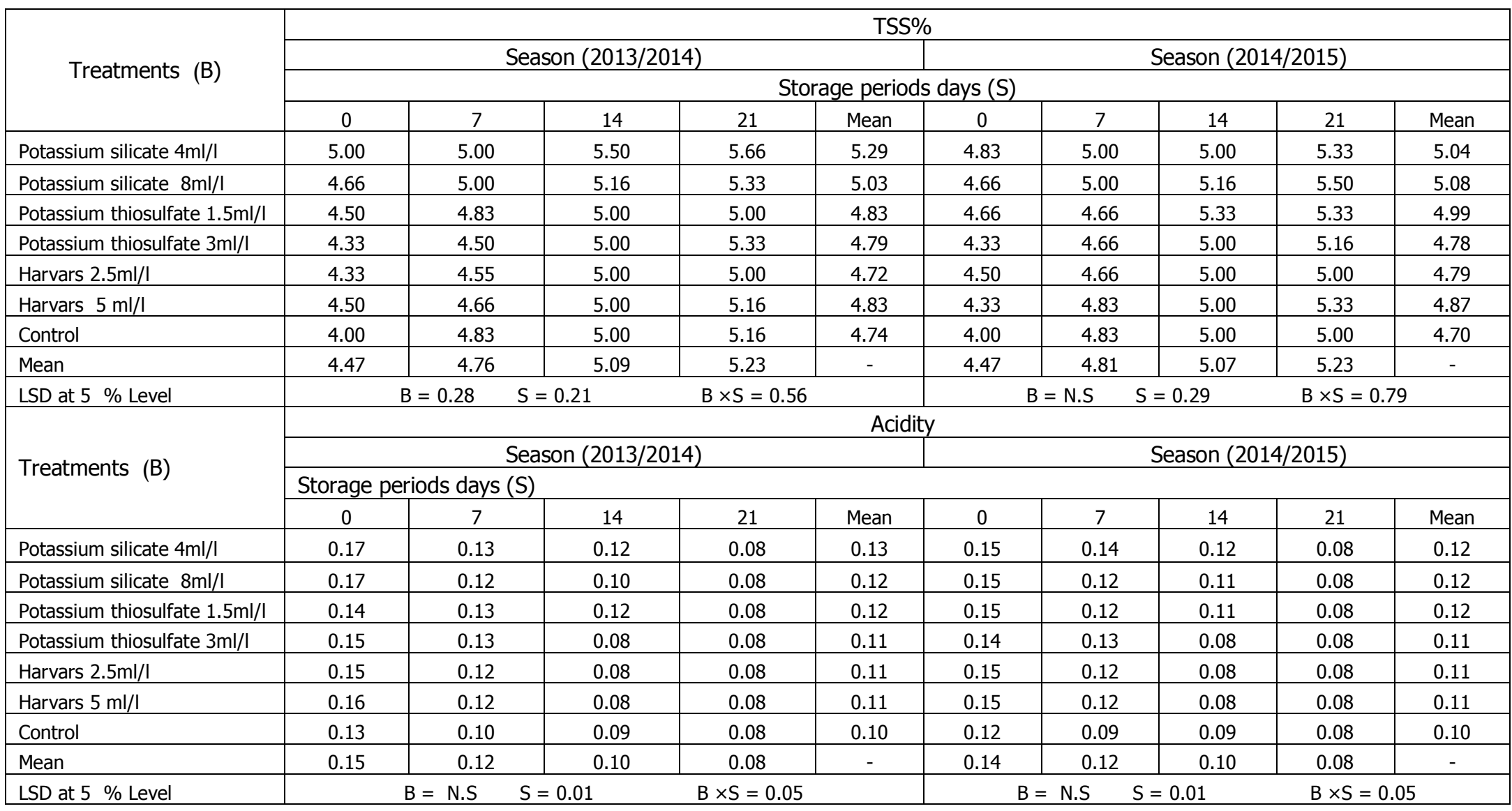


Table 6. Effect of pre-harvest potassium and silicon treatments on ascorbic acid content (mg/ $100 \mathrm{~g} \mathrm{fw})$ of sweet pepper during storage.

\begin{tabular}{|c|c|c|c|c|c|c|c|c|c|c|}
\hline \multirow{4}{*}{ Treatments (B) } & \multicolumn{10}{|c|}{ Ascorbic acid (mg/100g fw) } \\
\hline & \multicolumn{5}{|c|}{ Season $(2013 / 2014)$} & \multicolumn{5}{|c|}{ Season $(2014 / 2015)$} \\
\hline & \multicolumn{10}{|c|}{ Storage periods days (S) } \\
\hline & 0 & 7 & 14 & 21 & Mean & 0 & 7 & 14 & 21 & Mean \\
\hline Potassium silicate 4ml/l & 112.44 & 103.65 & 102.90 & 90.35 & 102.33 & 113.55 & 105.95 & 94.60 & 89.70 & 100.95 \\
\hline Potassium silicate $8 \mathrm{ml} / \mathrm{l}$ & 112.55 & 99.45 & 93.60 & 81.53 & 96.78 & 113.80 & 96.20 & 94.90 & 79.90 & 96.20 \\
\hline Potassium thiosulfate $1.5 \mathrm{ml} / \mathrm{l}$ & 112.08 & 99.56 & 94.08 & 62.40 & 92.03 & 113.01 & 98.21 & 91.65 & 59.15 & 90.50 \\
\hline Potassium thiosulfate $3 \mathrm{ml} / \mathrm{l}$ & 112.10 & 99.98 & 94.07 & 60.45 & 91.65 & 113.58 & 89.30 & 78.65 & 63.45 & 86.24 \\
\hline Harvars $2.5 \mathrm{ml} / \mathrm{l}$ & 112.13 & 89.37 & 80.6 & 68.20 & 87.57 & 113.80 & 91.65 & 83.03 & 64.35 & 88.20 \\
\hline Harvars $5 \mathrm{ml} / \mathrm{l}$ & 112.43 & 93.29 & 85.45 & 61.75 & 88.23 & 113.76 & 94.78 & 92.30 & 68.25 & 92.27 \\
\hline Control & 112.25 & 87.02 & 63.70 & 60.36 & 80.83 & 111.70 & 87.93 & 65.65 & 57.18 & 80.62 \\
\hline Mean & 112.28 & 96.04 & 87.77 & 69.29 & - & 113.31 & 94.86 & 85.82 & 68.85 & - \\
\hline LSD at $5 \%$ Level & & 2.59 & & $B \times S=5$ & & & 2.81 & 2.12 & $\mathrm{~B} \times \mathrm{S}=$ & \\
\hline
\end{tabular}




\section{REFERENCES}

1. O. A. C., 2000. Official Methods of Analysis. $17^{\text {th }}$ ed. Published by AOAC International, Maryland, USA.

2. Afifi, E. H. E., 2016. Effect of some pre-and postharvest treatments on storability of strawberry fruits. M.Sc. Thesis. Faculty of Agriculture Ain Shams University.

3. Cheisa, A.; D. Frezza; A. Fraschina; G. Trinchero; S. Moccia and A. Leon. 2003. Per harvest factors and fresh cut vegetables quality. Acta Hort. 604.

4. Cong, P.; C. Sat and R. Hardter. 2001. Response of selected crops to K fertilization on major soil types in South Vietnam. Hort. Abst., 72 (3): 3085.

5. El- Bassiony, A. M, Z. F. Fawzy, E. H. Abd El-Samad, and G. S. Riad. 2010. Growth,yield and fruit quality of sweet pepper plants (Capsicum annuumm L.) as affected by potassium fertilization. Journal of American Science, 6 (12):722-729.

6. Hou, L., E. Szwonek, and S. Xing. 2006. Advances in silicon research of horticultural crops. Vegetable Crops Research Bulletin 64. Research Institute of Vegetable Crops. Instytut Warzywnictwa Skieniewice, Poland.

7. Howard L.R, R.T, Smith, A.B. Wagner, B, Villalion E.E., Burns. 1994. Provitamin $A$ and ascorbic acid content of fresh pepper cultivars (Capsicum annuum) and processed jalapenos. J. Food Sci. 59: 362-365.

8. Jayawardana, H.A.R.K., H.L.D.Weerahewa, and M.D.J.S Saparamadu. 2014. Effect of root or foliar application of soluble silicon on plant growth, fruit quality and anthracnose development of capsicum. Tropical Agricultural Research 26(1):74-81.

9. Jifon, J., and G. Laster. 2012. Effects of foliar potassium fertilization on muskmellon fruit quality and yield.HortScience, 40(6):1862-1867.

10. Jifon, J., G. Laster, and D. I. Leskovar. 2009. Improving the quality attributes of melons through modified mineral nutrition. Acta Hort. No 841:573-540.

11. Kader, A.A. 2002. Postharvest Technology of Horticultural Crops. Third edition. University of California Agriculture and Natural Resources Publication, $3311 \mathrm{p}$.

12. Kaluwa, K., I. Bertling, J. P. Bower and S. Z. Tesafy. 2010.Silicon application effects on "Hass" avocado fruit physiology. South African Avocado Growers Association, Year Book, 33pp.

13. Krauss, A. 2000. Potash, the important part of balanced fertilization for high yield and good quality. Potash Workshop, October 10, 2000, Tirana, Albania.

14. Liang, Y.,W.Sun,Y.G.Zhu and P. Christie. 2007. Mechanisms of silicon -mediated alleviation of a biotic stress in higher plants: A review. Environ. Pollut., 147:422428.

15. Lyyakkannu, S., M. S. Son., C. S. Lim, and B. R.Jeong (2011). Effect of soaking of seeds in potassium silicate and uniconazole on germination and seedling growth of tomato cultivars, Seageon and Seokwang. African Journal of Biotechnology, 10 (35):6743-6749. 
16. Maalekuu K, Elkind Z, Tuvia-Alkalai S, Shalom Y, Fallik E. 2002. Quality evaluation of three sweet pepper cultivars after prolonged storage. Adv. Hort. Sci. 17: 187-191.

17. Rao, T. V. R, N. B. Gol, and K. K. Shah. 2011. Effect of postharvest treatments and storage temperatures on the quality and shelf life of sweet pepper (Capsicum annuum L.).Scientia Horticulturae 132:18-26.

18. Sakaldas, M., and K., Kaynas. 2010. Biochemical and quality parameters changes of green sweet bell peppers as affected by different postharvest treatments. African Journal of Biotechnology, 9 (48): 8174-8181.

19. Sams, C.E. 1999. Preharvest factors affecting postharvest texture. Postharvest Biology and Technology 15: 249-254.

20. Sethu, P. K. M. T. N. Prabha and R. N. Tharanathant 1996. Post-harvest biochemical changes associated with the soffening phenomenon in capsicum annuum fruits. Phvtochemistry, 42 (4): 961-966.

21. Shetty, R., B.Jensen, N.P.Shetty, M. Hansen, C. W. Hansen, K. R Starkey and H.J.L.Jørgensen (2012). Silicon induced resistance against powdery mildew of roses caused by padosphaera pannosa Plant Pathol.61:120-131.

22. Silva, M.L., J.T. Resende, A.R. Trevizam, A.S.Figueiredo and K.Schwarz. 2013. Influence of silicon on production and fruit quality of strawberry. Semina .Ciências Agrárias (Londrina)., 34(6):3411-3424.(abstr).

23. Smith,LD, J. R. Stommel, R. W.M. Fung, C. Y. Wang, and B. D. Whitaker. 2006. Influence of cultivar and harvest method on postharvest storage quality of pepper (Capsicum annuum L.) fruit. Postharvest Biology and Technology, 42: 243-247.

24. Snedecor, G. W. and W. G. Cochran. 1980. Statistical Methods. $7^{\text {th }}$ Ed. The Iowa State Univ., Press, Amer., Iowa, USA.

25. Stamatakis, A., N. Papadantonakis, N. Lydakis-Simantiris, P. Kefalas and D. Savvas 2003. Effects of silicon and salinity on fruit yield and quality of tomato grown hydroponically. Acta Hortic., 609: 141-147.

26. Tarabih, M. E., E. E. EL-Eryan and M. A. El-Metwally 2014. Physiological and pathological impacts of potassium silicate on storability of anna apple fruits. Am.J.Plant PhysioL., 9:52-67.

27. Tesfay, S. Z., I. Bertling, and J. P. Bower. 2011. Effects of postharvest potassium silicate application on phenolics and other ant- oxidant system aligned to avocado fruit quality. Postharvest Biology and Technology, 60:92-99.

28. Wills, R., B. McGlasson, D. Graham and D. Joyce. 1998. Postharvest: An introduction to the physiology and handling of fruit, vegetables and ornamentals (4th ed., pp. 77-96). New York: CAB International, Wallingford, UK.

29. Xing, Y., X. Li, Q. Xu, J. Yun, Y. Lu, and Y. Tang. 2011. Effects of chitosan coating enriched with cinnamon oil on qualitative properties of sweet pepper. Food Chemistry, 124:1443-1450. 
تأثثير الرش الورقى قبل الحصاد بالبوتاسيوم والسليكون على الجوده والقدره التخزينيه للفلقل الحلو

أمل سيد حسن عتريس'، اسماعيل عبد اللطيف سليمان رشيد

ا ـ قسم تداول الخضر - معهز بحوث البساتين - مركز البحوث الزراعية - الجيزة - مصر r. قسم بحوث امراض ما بعد الحصاد - معهز بحوث امراض النباتات - مركز البحوث

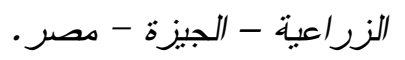

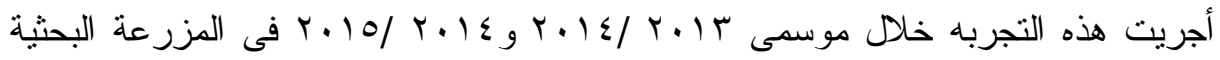

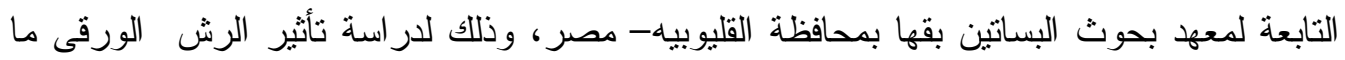
قبل الحصاد لنباتات الفلفل الحلو صنف سونار بتركيزات عو ^ مل/لتز من سليكات البوتاسيوم، $1 ،$

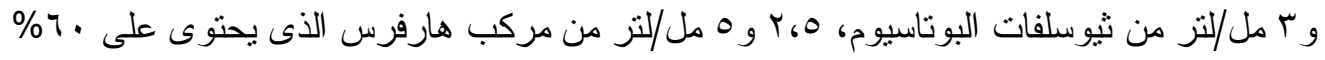

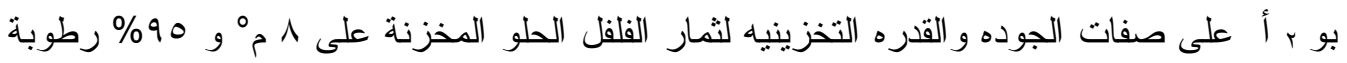
نسبيه لمدة إ يوم. وقد بينت النتائج حدوث تحسن فى وزن الثرة ولمعان الثره و كذللك اللون الاخضر للثمرة وقت الحصاد عند رش نباتات الفلفل الأخضر قبل الحصاد بكل من سليكات

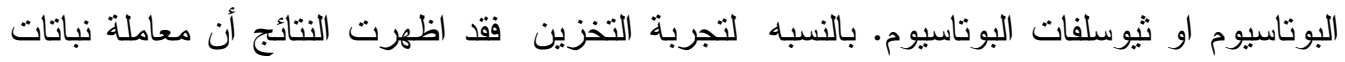

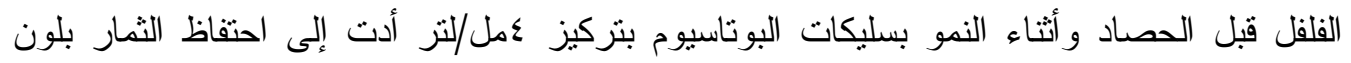

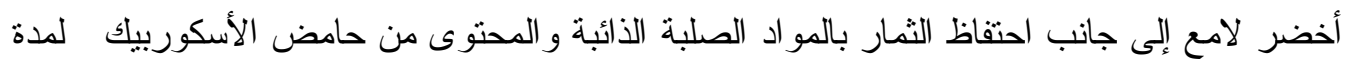

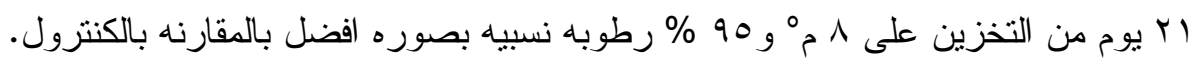

